\title{
SOME OBSERVATIONS ON TAMARACK OR EASTERN LARCH
}

\author{
(Larix laricina Koch.)
}

\author{
By H. H. BEEFTINK
}

Calgary, Alberta

In Alberta tamarack is usually found in swampy country. In such an area, in the Calling Lake-Lesser Slave Lake region, the writer recently observed some features which may be of special interest.

The tamarack is extremely intolerant of shade and this intolerance determines the place where the tree can grow. In the Alberta region studied, it was observed that young seedlings were to be found in open swamps, or on poorly drained, burned-over areas where competing vegetation was absent.

The swamp apparently offers the best site for germination and growth of these trees. Here most of the seedlings germinate on little rises of the surface, which are above the springtime water level. A favourable site for germination seems to be a clump of sphagnum moss with some scattered sedges. The reason for this may be the fairly constant moisture regime in the moss, or the negligible competition for light. The latter factor may be the more important one, for it was obvious that where much Labrador tea (Ledum groenlandicum Oeder.) occurred together with sphagnum, not many tamarack seedlings could survive in the resulting shade.

Most tamarack seedlings are accompanied by swamp birch (Betula glandulosa Michx.) another species with similar silvical characteristics. However, where the birch does not appear, very few or no tamarack seedlings can be found. This strongly suggests that on areas where birch is present the site is good for tamarack germination.

The young larch is more of a pioneer plant in the wetter stage of the swamp vegetation than is black spruce (Picea mariana (Mill.) B.S.P.). Many places show a primary migration of larch toward the centre of the swamp, with an outer border of black spruce invading the originally established larch where the growing sphagnum has raised the soil surface sufficiently above the water table. Often an abundance of Labrador tea and sometimes blueberry ( $V a c$ cinium canadense Kulm.) accompanies the black spruce. Where competition is so strong no new germination of tamarack can be found.

The aerial part of the young tree, growing only $1 / 2^{\prime \prime}$ to $2^{\prime \prime}$ a year, is developing at a critical rate in constant competition with the sphagnum. This struggle for life can go on for eight years and more. If it survives this period the tree growth gradually picks up. Larches on wet sites develop no taproots. The seedling appears to spread its fine lateral roots adequately throughout the moss. The original root system apparently does not receive enough oxygen after a few years, and its growth almost stops. However, as the moss overgrows the cotyledon whorl of the seedling, a new set of roots develops from this point. Such root production is not limited to the first node. In successive years the developing sphagnum advances up the stem and new roots develop from each of the nodes as they are buried. Some internodal roots 
may appear as well from the moss-covered stem. The buried dead needles on the former aerial parts are often visible far below the highest roots.

Not only the tamarack shows the new development of the roots, but the same can be seen on some young black spruce.

Early tamarack roots grow slowly and stay small. As soon as the young tree develops an annual terminal growth of more than about two inches (3-8 years) the crucial stage of survival has been passed. Now the roots start to grow at a tremendous speed, and a lateral growth of four feet a year is not rare. It seems that these new thick roots grow into the zone of maximum available plant nutrients in the mineral-poor sphagnum, for no fine lateral roots can be seen as would be the case if this rapid growth were for the main purpose of seeking oxygen. The new roots always stay in the top moss layer and do not go deeper than five inches. In their second year, they develop short side roots, which carry mycorrhiza to supply nitrogenous food for the tree.

Once established, the root system spreads on a favourable site over an area whose radius is greater than the height of the tree. This applies to old open-grown trees as well as to younger ones.

A severe setback to growth in early years is caused by rabbits, which chew the saplings off as much as two or three inches above the ground. The tamarack tends to overcome the damage either by sending up as a leader one of its small side branches or by developing a dormant bud.

An average loss of height growth of ten years is probably a low estimate. In a succession of years with little rabbit damage, growth continues by as much as $11 / 2$ feet a year. On a good site the tree can maintain this average for at least 20 to 30 years.

As soon as the stand closes the growth drops to a very low level. Young tamarack initially shows a better growth than nearby black spruce. After a few years, however, the spruce takes over and the tamarack falls into a decline. Thorough thinning can prevent this setback. Such thinning can result from a light burn, to which the black spruce seems to be less resistant. Any fire scars on the surviving tamarack are usually covered in time by callus growth even though decay may have entered. 